\title{
Effects of Reheating Conditions and Sodium Chloride/Phosphate Levels on Color Characteristics of Precooked Pork Patties
}

\author{
Ji-Hun Choi, Yun-Sang Choi, Doo-Jeong Han¹, Hack-Youn Kim¹, Mi-Ai Lee', Si-Young Kim¹, \\ Ju-Woon Lee ${ }^{2}$, Jong-Youn Jeong ${ }^{3}$, and Cheon-Jei Kim ${ }^{1, *}$ \\ Research Institute for Meat Science \& Culture, Konkuk University, Seoul 143-701, Korea \\ ${ }^{1}$ Department of Food Science and Biotechnology of Animal Resources, Konkuk University, Seoul 143-701, Korea \\ ${ }^{2}$ Team for Radiation Food Science and Biotechnology, Radiation Technology Institute, \\ Korea Atomic Energy Research Institute, Jeongeup 580-185, Korea \\ ${ }^{3}$ Department of Animal Science, Michigan State University, East Lansing, MI 48824, United States
}

\begin{abstract}
The objective of this study was to determine the effect of reheating methods on the color characteristics of precooked pork patties with various $\mathrm{NaCl}$ and phosphate levels. $\mathrm{NaCl} /$ phosphate levels for each formulation were as follows; $\mathrm{N} 1(1 \% \mathrm{NaCl})$, $\mathrm{N} 1+\mathrm{P}(1 \% \mathrm{NaCl}+0.3 \%$ phosphate $), \mathrm{N} 2(2 \% \mathrm{NaCl})$, and $\mathrm{N} 2+\mathrm{P}(2 \% \mathrm{NaCl}+0.3 \%$ phosphate). The reheating methods used were by electric grill and microwave oven. The surface color of the patties reheated by microwave showed more brown and less-intense red, and the phosphate-treated patties reheated by microwave were more reddish and less brownish. With increased amounts of added $\mathrm{NaCl}$ and phosphate, the internal color of patties was more reddish, and the phosphate-treated patties reheated by microwave had more brown than those reheated by electric grill. Among all of the treatments, there were no significant differences in surface color, internal color, and overall appearance. Thus, the color changes in reheated patties were influenced by reheating methods and phosphate.
\end{abstract}

Key words: reheating method, $\mathrm{NaCl}$, phosphate, meat color, ground pork patty

\section{Introduction}

Recently, food products that can be reheated using various cooking methods (electric grill, convection oven, and microwave oven) with the food still have become popular, but it is difficult to heat them uniformly. This is because meat products are affected by various factors, such as dielectric and thermal properties (Shiffman, 1986), the composition and geometry of product (Ryyänen, 1995), composition of product (Brican and Barringer, 2002; Ryyänen and Ohlsson, 1996; Ryyänen et al., 2004), and cooking methods. Cooking methods are largely responsible for many aspects of the final quality of meat products, and the selection of an appropriate heating method for cooking can affect not only quality but also production cost (Barbut and Mittal, 1990). Berry and Leddy (1984), El-Shimi (1992), and Serrano et al. (2007) compared

*Corresponding author: Cheon-Jei Kim, Department of Food Science and Biotechnology of Animal Resources, Konkuk University, Seoul 143-701, Korea. Tel: 82-2-450-3684, Fax: 82-2-444-6695, E-mail: kimcj@konkuk.ac.kr microwave cooking with conventional cooking. Choi et al. (2008a), Jeong et al. (2004), and Kirchner et al. (2000) studied how to use a microwave oven not in simply reheating precooked products but in directly cooking raw meat products.

The consumer in Europe and America take in processing meat products rather than preferring meat itself and eat to cold state with bread or salad. But Korean consumers mainly eat by griddling and boiling bacons of various pork parts, and by warming or reheating precooked meat products. Also, consumers want to eat convenient and ready-to-cook meals due to the increase of a nuclear family, single life, and women's employment. Recently, the improvement, diversification, and convenience of our diets have been increased to the use of ready prepared foods such as frozen foods, and the foods are vigorously supplied through reheating by cooked/chilled food service systems in food service operations. Commercial precooked meat products may be frozen uncooked, frozen cooked, or cooked and stored at refrigerator temperature. Since pre-cooked meat products such as patties and sausages are stored chilled or frozen, consumers use many 
cooking methods for reheating and eating. A major problem with manufacturing restructured and other comminuted meat products is maintaining the cooked color of itself. When meat products are cooked, their color changes from red to brown due to the formation of ferro/ferrihaemochrome. Also, the reheating of precooked products results in lipid oxidation and pigment oxidation, thus, the quality changes of cooked products are caused by additives such as salt and phosphate (Choi et al., 2008b). The sodium chloride $(\mathrm{NaCl})$ and phosphates are used in processed-meat formulations to increase water holding capacity (Keeton, 1983) and to stabilize color (Offer and Trinick, 1983). Also, the myoglobin oxidation was affected by pH (Brown and Mebine, 1969) and salt type and concentration (Wallace et al., 1982). Thus, maintaining a satisfactory color in ground meat products is difficult. In order to minimize the color change and myoglobin oxidation of meat products by reheating, it is necessary to make a basic study on adequate reheating temperature and time for various cooking methods such as conventional and microwave cooking.

Therefore, the objective of this study was to determine the effect of reheating methods on the color characteristics of precooked ground pork patties with various $\mathrm{NaCl} /$ phosphate levels.

\section{Materials and Methods}

\section{Preparation of patty}

Fresh pork ham (M. biceps femoris, M. semitendinosus, and M. semimembranosus) were purchased from a local processor at $48 \mathrm{~h}$ postmortem. Pork back fat was also collected. All subcutaneous and intermuscular fat and visible connective tissue were removed from the fresh ham muscles. The fat content and $\mathrm{pH}$ of the trimmed pork were $5.12 \pm 0.12 \%$ and $5.65 \pm 0.14$, respectively. Lean muscles were initially ground through a $\varnothing-13 \mathrm{~mm}$ plate and the pork back fat was ground through a Ø-8 $\mathrm{mm}$ plate using a meat grinder ( $p$ M-70, Mainca, Spain). The ground meat and fat were vacuum-packaged in polyethylene bag (permeation $\left(\mathrm{cm}^{3}(\mathrm{~mL}, \mathrm{cc}) / \mathrm{m}^{2}\right.$ day: bar): $\mathrm{CO}_{2}: 42,500, \mathrm{~N}_{2}$ : 2,800, $\mathrm{O}_{2}: 7,900$; water vapor transmission $\left(\mathrm{g} / \mathrm{m}^{2}\right.$ day bar): $24-48$, use temperature $\left.\left({ }^{\circ} \mathrm{C}\right):-50-+90\right)$ and stored at $4^{\circ} \mathrm{C}$ for $3 \mathrm{~d}$.

The compositions of all patties are shown in Table 1. $\mathrm{NaCl}$ and phosphate levels for each formulation were as follows; $\mathrm{N} 1(1 \% \mathrm{NaCl}), \mathrm{N} 1+\mathrm{P}(1 \% \mathrm{NaCl}$ and $0.3 \%$ phosphate), $\mathrm{N} 2(2 \% \mathrm{NaCl})$, and $\mathrm{N} 2+\mathrm{P}(2 \% \mathrm{NaCl}$ and $0.3 \%$ phosphate). Each batch of meat and fat was mixed by
Table 1. The composition of the pork patties with different $\mathrm{NaCl} / \mathrm{phosphate} \mathrm{levels}$

\begin{tabular}{lrrrr}
\hline \hline \multicolumn{1}{c}{ Traits $(\mathrm{g})$} & $\mathrm{N} 1$ & $\mathrm{~N} 1+\mathrm{P}$ & $\mathrm{N} 2$ & $\mathrm{~N} 2+\mathrm{P}$ \\
\hline Pork lean meat & 792 & 790 & 784 & 782 \\
Pork back fat & 198 & 197 & 196 & 196 \\
$\mathrm{NaCl}$ & 10 & 10 & 20 & 20 \\
Sodium tripolyphosphate & - & 3 & - & 3 \\
Total & 1000 & 1000 & 1000 & 1000 \\
\hline
\end{tabular}

hand for 3 min. After $\mathrm{NaCl}$ (Natural hanju salt, Hangu Corp., South Korea) and sodium tripolyphosphate (Dongbang Foodmastar, South Korea) were added, the batches were mixed for an additional $3 \mathrm{~min}$ and then mixed for 30 min at $4^{\circ} \mathrm{C}$ using a meat mixer (RM-90, Mainca, Barcelona, Spain). Before patties were formed, the batches were held at $4^{\circ} \mathrm{C}$ for $1 \mathrm{~h}$ (Trout and Dale, 1990). The batches were formed into $120 \pm 1 \mathrm{~g}$ patties with a diameter of $100 \mathrm{~mm}$ and a thickness of $15 \mathrm{~mm}$ using a patty press (Small Round Press, Spikomat Ltd., UK), and then stored at $4^{\circ} \mathrm{C}$ for $24 \mathrm{~h}$.

\section{Cooking and reheating methods}

Patties were cooked on a preheated electric grill (CG20, Hobart, USA) at a grill surface temperature of $150^{\circ} \mathrm{C}$. Patties were cooked for $3 \mathrm{~min}$ on one side and for $3 \mathrm{~min}$ on the opposite side, and thereafter flipped over every 2 min until the targeted core temperature reached $76.5^{\circ} \mathrm{C}$. This temperature is selected to destroy Trichinella spiralis survived in pork products (Zimmermann, 1984). The core temperature of the patties was monitored with a digital thermometer (Tes-1305, Tes Electrical Corp., Taiwan) equipped with a data logger (RS-232, Tes Electrical Corp., Taiwan) by inserting an iron constantan thermocouple. After a cooking was completed, the patties were held for $2 \mathrm{~min}$ in room temperature and the temperature changes were measured continuously. The patties were stored at $0^{\circ} \mathrm{C}$ for $5 \mathrm{~d}$. The cooking times necessary for each type of patty were: $\mathrm{N} 1$ treatment $=680.5 \pm 22.1 \mathrm{~s}$; N1 $+\mathrm{P}$ treatment $=689.5 \pm 22.4 \mathrm{~s} ; \mathrm{N} 2$ treatment $=700.5 \pm 30.0$ $\mathrm{s} ; \mathrm{N} 2+\mathrm{P}$ treatment $=719.0 \pm 35.7 \mathrm{~s}$ (Choi et al., 2008b).

The used reheating methods were an electric grill and a microwave oven reheating. Electric grill reheating was conducted as described on cooking method. Precooked patties were only reheated as described above until the internal temperature of the patty reached to $74^{\circ} \mathrm{C}$ (Cremer and Hartley, 1988). For reheating by microwave oven, patties were cooked in a household-type microwave oven (NN-S963/S763, Panasonic Inc., Canada) at medium-high power $(750 \mathrm{~W})$ operating at $2450 \mathrm{MHz}$ according to the 
"operation instruction" of the microwave oven, since full power $(1250 \mathrm{~W})$ caused deterioration of the patties. Each patty was placed in the center of the oven on a microwave-safe plastic container with a plastic rack (approximately $8 \mathrm{~mm}$ from the bottom of the container), which allowed drippings to escape from the underside, until the targeted center temperature of $74^{\circ} \mathrm{C}$ was reached. The container was also rotated in the oven during cooking.

\section{pH measurement}

The $\mathrm{pH}$ of each sample was determined with a $\mathrm{pH}$ meter (Model 340, Mettler-Toledo GmbH, Switzerland). The $\mathrm{pH}$ value was measured by blending a $5 \mathrm{~g}$ sample with 20 $\mathrm{mL}$ distilled water for $60 \mathrm{~s}$ in a homogenizer (Ultra-Turrax T25, Janke \& Kunkel, Germany).

\section{Instrumental color measurement}

For instrumental color measurements, raw, cooked, and reheated patties were cut just off the center (horizontal to the patty flat surface) and color values of the surface and internal cut sides were determined. Instrumental color measurements were taken with a colorimeter (Chroma meter CR-210, Minolta, Japan; illuminate C, calibrated with white standard plate $\left.\mathrm{CIE}^{*}=97.83, \mathrm{a}^{*}=-0.43, \mathrm{~b}^{*}=+1.98\right)$. Hue angle $\left(\mathrm{H}^{*}\right)$ and $\mathrm{S}$-chroma $\left(\mathrm{S}^{*}\right)$ were calculated using methods of Hunter and Harold (1987).

$$
\mathrm{H}^{*}=\tan ^{-1} \frac{\mathrm{b}^{*}}{\mathrm{a}^{*}} \quad \mathrm{~S}^{*}=\left(\mathrm{a}^{* 2}+\mathrm{b}^{* 2}\right)^{1 / 2}
$$

\section{Myoglobin denaturation (Mb) and percent met- myoglobin}

All cooked and reheated samples were analyzed for myoglobin denaturation and percent metmyoglobin. Myoglobin and metmyoglobin were extracted by a modification of procedures by Warriss (1979). Briefly, samples were blended with 5 volumes of cold $0.04 \mathrm{M}$ phosphate buffer at $\mathrm{pH} 6.8$ for $10 \mathrm{~s}$ in a homogenizer (Model AM-7, Nihonseiki Kaisha Ltd., Japan). After standing at $1{ }^{\circ} \mathrm{C}$ for $1 \mathrm{~h}$, the mixtures were centrifuged at $3500 \times \mathrm{g}$ at $4^{\circ} \mathrm{C}$ for $30 \mathrm{~min}$. The supernatant was further clarified by filtration through Whatman No. 1 filter paper. The absorbance of filtrate was measured at 525, 572, $700 \mathrm{~nm}$ using a spectrophotometer (Optizen III, Mecasys, Korea). The myoglobin concentration and percent metmyoglobin were calculated using the following Kryzwicki's equation (1979):

\section{Myoglobin content $(\mathrm{mg} / \mathrm{mL})$}

$$
=\left(\mathrm{A}_{525}-\mathrm{A}_{700}\right) \times 2.303 \times \text { dilution factor }
$$

Metmyoglobin (\%)

$=\left[1.395-\left(\mathrm{A}_{572}-\mathrm{A}_{700}\right) /\left(\mathrm{A}_{525}-\mathrm{A}_{700}\right)\right] \times 100$

Where $\mathrm{A}_{\lambda}=$ Absorbance at $\lambda \mathrm{nm}$

Pecent myoglobin denatured during cooking was calculated using the following formula:

$$
\begin{aligned}
& \text { Mb denaturation }(\%)= \\
& \frac{\mathrm{Mb} \text { cont. in raw patties }-\mathrm{Mb} \text { cont. in cooked patties }}{\text { Mb cont. in raw patties }}
\end{aligned}
$$

\section{Visual color and appearance evaluation}

Immediately following cooking and weighing, cooked and reheated patties were sliced parallel to the flat surface in the center of samples. The surface and internal color of each patty were evaluated by a 10 -member trained panel using a 10 -point horizontal scale $(1=$ pink, $10=$ extremely brown). The overall appearance were also evaluated $(1=$ extremely undesirable, 10 = extremely desirable).

\section{Statistical analysis}

An analysis of variance were performed on all the variables measured using the General Linear Model (GLM) procedure of the SAS statistical package (SAS, 1999). The Duncan's multiple range test $(p<0.05)$ was used to determine differences between treatment means.

\section{Results and Discussion}

\section{Color properties of raw and cooked pork patties}

Table 2 shows the quality characteristics of raw ground pork patties with different $\mathrm{NaCl}$ and phosphate level. The $\mathrm{pH}$ of $\mathrm{N} 2+\mathrm{P}$ treatment (6.06) showed a significantly higher value than those (5.86-5.96) of other treatments $(p<0.05)$ due to the addition of more $\mathrm{NaCl}$ and phosphate. CIE L*-value (lightness) was not significantly different among the treatments, but the $\mathrm{N} 2+\mathrm{P}$ treatment showed higher CIE $\mathrm{a}^{*}$-value (redness) and CIE $\mathrm{b}^{*}$-value (yellowness) than the other treatments $(p<0.05)$. Hue angle (higher values are more brown) of $\mathrm{N} 2+\mathrm{P}$ treatment had the lowest and S-chroma values (higher values are more intense red) were highest values of all treatments, but myoglobin contents were not significantly different among the treatments $(p>0.05)$. These results are similar to studies of Keeton (1983). As a result, the addition of different levels of $\mathrm{NaCl}$ and phosphate had an effect on the $\mathrm{pH}$ and color of raw patties during the process.

Table 3 shows instrumental color characteristics of cooked pork patties with different $\mathrm{NaCl} /$ phosphate levels. 
Table 2. Comparison on the instrumental color characteristics of the raw pork patties with different $\mathrm{NaCl} / \mathrm{phosphate} \mathrm{levels}$

\begin{tabular}{lcccc}
\hline \multirow{2}{*}{ Traits } & \multicolumn{4}{c}{ Treatments $^{1)}$} \\
\cline { 2 - 5 } & $\mathrm{N} 1^{1)}$ & $\mathrm{N} 1+\mathrm{P}$ & $\mathrm{N} 2$ & $\mathrm{~N} 2+\mathrm{P}$ \\
\hline CIE L $^{*}$ & $59.33 \pm 1.25$ & $59.58 \pm 1.56$ & $59.64 \pm 1.72$ & $60.36 \pm 1.13$ \\
CIE a $^{*}$ & $13.10 \pm 1.02^{\mathrm{C}}$ & $13.42 \pm 1.15^{\mathrm{BC}}$ & $14.41 \pm 1.05^{\mathrm{B}}$ & $16.85 \pm 0.87^{\mathrm{A}}$ \\
CIE b $^{*}$ & $9.61 \pm 0.66^{\mathrm{B}}$ & $9.48 \pm 0.98^{\mathrm{B}}$ & $10.05 \pm 0.81^{\mathrm{AB}}$ & $10.44 \pm 0.74^{\mathrm{A}}$ \\
Hue angle & $36.32 \pm 2.22^{\mathrm{A}}$ & $35.23 \pm 2.39^{\mathrm{A}}$ & $34.90 \pm 1.66^{\mathrm{A}}$ & $31.77 \pm 1.92^{\mathrm{B}}$ \\
S-chroma & $16.25 \pm 1.04^{\mathrm{C}}$ & $16.44 \pm 1.35^{\mathrm{BC}}$ & $17.58 \pm 1.22^{\mathrm{B}}$ & $19.83 \pm 0.93^{\mathrm{A}}$ \\
Myoglobin content (mg/mL) & $1.59 \pm 0.28$ & $1.54 \pm 0.15$ & $1.51 \pm 0.28$ & $1.57 \pm 0.29$ \\
\hline
\end{tabular}

All values are means \pm standard deviation.

${ }^{1)} \mathrm{N} 1$ : patties containing $1 \% \mathrm{NaCl}$ and no phosphate, $\mathrm{N} 1+\mathrm{P}$ : patties containing $1 \% \mathrm{NaCl}$ and $0.3 \%$ phosphate, $\mathrm{N} 2$ : patties containing $2 \%$ $\mathrm{NaCl}$ and no phosphate, $\mathrm{N} 2+\mathrm{P}$ : patties containing $2 \% \mathrm{NaCl}$ and $0.3 \%$ phosphate.

${ }^{A-C}$ Mean values with different superscripts within a same row are significantly different $(p<0.05)$.

Table 3. Comparison on the instrumental color characteristics of the cooked pork patties with different $\mathrm{NaCl} / \mathrm{phosphate} \mathrm{levels}$

\begin{tabular}{|c|c|c|c|c|}
\hline \multirow{2}{*}{ Traits } & \multicolumn{4}{|c|}{ Treatments ${ }^{1)}$} \\
\hline & N1 & $\mathrm{N} 1+\mathrm{P}$ & $\mathrm{N} 2$ & $\mathrm{~N} 2+\mathrm{P}$ \\
\hline \multicolumn{5}{|l|}{ Surface color } \\
\hline CIE L* & $55.88 \pm 2.01$ & $56.56 \pm 2.11$ & $55.18 \pm 2.15$ & $55.96 \pm 2.84$ \\
\hline CIE a* & $6.38 \pm 0.63^{\mathrm{A}}$ & $5.79 \pm 0.52^{\mathrm{B}}$ & $6.05 \pm 0.52^{\mathrm{AB}}$ & $5.64 \pm 0.55^{\mathrm{B}}$ \\
\hline CIE b* & $13.45 \pm 1.13$ & $12.74 \pm 1.15$ & $12.80 \pm 1.14$ & $13.30 \pm 1.28$ \\
\hline Hue angle & $64.54 \pm 2.84^{\mathrm{B}}$ & $65.47 \pm 2.30^{\mathrm{AB}}$ & $64.63 \pm 2.22^{\mathrm{B}}$ & $66.90 \pm 2.93^{\mathrm{A}}$ \\
\hline S-chroma & $14.90 \pm 1.05^{\mathrm{A}}$ & $14.00 \pm 1.12^{\mathrm{B}}$ & $14.17 \pm 1.12^{\mathrm{B}}$ & $14.46 \pm 1.20^{\mathrm{AB}}$ \\
\hline \multicolumn{5}{|l|}{ Internal color } \\
\hline CIE L* & $67.02 \pm 0.43^{\mathrm{A}}$ & $65.77 \pm 0.39^{\mathrm{AB}}$ & $64.74 \pm 0.75^{\mathrm{B}}$ & $64.06 \pm 0.58^{\mathrm{B}}$ \\
\hline CIE $a^{*}$ & $4.88 \pm 0.39^{\mathrm{B}}$ & $5.48 \pm 0.19^{\mathrm{A}}$ & $5.05 \pm 0.37^{\mathrm{B}}$ & $5.54 \pm 0.17^{\mathrm{A}}$ \\
\hline CIE b* & $8.43 \pm 0.27^{\mathrm{A}}$ & $7.97 \pm 0.17^{\mathrm{B}}$ & $7.50 \pm 0.30^{\mathrm{C}}$ & $7.25 \pm 0.30^{\mathrm{C}}$ \\
\hline Hue angle & $59.94 \pm 2.38^{\mathrm{A}}$ & $55.53 \pm 1.18^{\mathrm{B}}$ & $56.07 \pm 2.33^{\mathrm{B}}$ & $52.58 \pm 1.63^{\mathrm{C}}$ \\
\hline S-chroma & $9.74 \pm 0.24^{\mathrm{A}}$ & $9.67 \pm 0.15^{\mathrm{A}}$ & $9.05 \pm 0.30^{\mathrm{B}}$ & $9.13 \pm 0.23^{\mathrm{B}}$ \\
\hline Myoglobin denaturation (\%) & $73.20 \pm 3.61$ & $69.34 \pm 3.10$ & $69.88 \pm 3.63$ & $72.25 \pm 1.82$ \\
\hline
\end{tabular}

All values are means \pm standard deviation.

${ }^{1)}$ The abbreviations are the same as in Table 2.

All raw patties were cooked by electric grill.

${ }^{A-C}$ Mean values with different superscripts within a same row are significantly different $(p<0.05)$.

The color of the ground beef and pork patties were influenced by cooking time (Liu and Berry, 1996), cooking temperature (Hague et al., 1994) and $\mathrm{pH}$ of meat (Trout, 1989). The additives such as salt and phosphate also caused the color changes in precooked meat products. As increased salt content and phosphate in the previous our study (Choi et al., 2008b), the cooking time increased. And the $\mathrm{pH}$ of the phosphate treatments (6.25-6.26) was higher than those of the not-phosphate treatments (6.106.11).

The surface CIE $\mathrm{L}^{*}$-value (lightness) and CIE $b^{*}$-value (yellowness) was not affected by $\mathrm{NaCl} /$ phosphate levels $(p>0.05)$. The surface CIE a ${ }^{*}$-value (redness) of $\mathrm{N} 1$ treatment were higher than those of $\mathrm{N} 1+\mathrm{P}$ and $\mathrm{N} 2+\mathrm{P}$ treatments and S-chroma (higher values are more intense red) were higher than those of $\mathrm{N} 1+\mathrm{P}$ and $\mathrm{N} 2$ treatments. Hue angle (higher values are more brownish) of surface patties without phosphate were lower $(p<0.05)$. The internal color of treatment with $1 \% \mathrm{NaCl}(\mathrm{N} 1)$ had higher $\mathrm{L}^{*}$ value than treatments with $2 \% \mathrm{NaCl}(\mathrm{N} 2$ and $\mathrm{N} 2+\mathrm{P})$. In particular, internal a ${ }^{*}$-value of patties with phosphate was significantly higher than that of patties without phosphate in opposition to results of surface $a^{*}$-value. Other color parameters such as $b^{*}$, hue angle, and S-chroma values were decreased with increase of $\mathrm{NaCl} /$ phosphate level $(p<0.05)$. Myoglobin denaturation was the range of 69 to $73 \%$, but that was not significantly different between all treatments $(p>0.05)$. Trout (1989) found percent myoglobin denaturation increased from $55^{\circ} \mathrm{C}$ to $83^{\circ} \mathrm{C}$ and the presence of sodium chloride and sodium tripolyphosphate increased the percent myoglobin denaturated. But in high temperature more than $75^{\circ} \mathrm{C}$, myoglobin denaturation 
didn't affect by cooking temperature rather than salt concentration. Especially, because the pork patties were cooked at $76.5^{\circ} \mathrm{C}$ for destroy Trichinella Spiralis (Zimmermann, 1984), the differences in the myoglobin denaturation of this study did not detect. The visual color properties of ground pork patties with different $\mathrm{NaCl}$ / phosphate levels are shown in Table 4. The surface color of $\mathrm{N} 2+\mathrm{P}$ treatment (8.26) was estimated superior to other treatments $(p<0.05)$. But internal color and overall appearance were not significantly different between four treatments $(p>0.05)$.

\section{Color properties of reheated pork patties}

\section{Reheating time and instrumental color characteristics}

Table 5 shows the reheating time of the reheated pork patties with different $\mathrm{NaCl} /$ phosphate levels. The precooked patties were reheated using electric grill and microwave oven. The reheating time of patties reheated using an electric grill required the extents of 740 to $760 \mathrm{~s}$ regardless of $\mathrm{NaCl}$ and phosphate levels $(p>0.05)$. On the other hand, the reheating time of patties reheated using a microwave oven required in the order: $\mathrm{N} 1<\mathrm{N} 2<\mathrm{N} 1+\mathrm{P}$ $<\mathrm{N} 2+\mathrm{P}$, that is, the addition of phosphate increased the reheating time of patties. And the patties were reheated 5 to 6 times faster than those using a microwave oven $(p<0.05)$. Chung and Chung (1993) studied that the rate of temperature rise in beef cooked using conventional heating is 10 to 20 times slower than that in beef cooked using microwave. Korschgen and Baldwin (1978) found that cooking time in a microwave oven was 3 times faster than that in electric grill. Also, this finding is similar to the result of Jeong et al. (2007), who showed that the addition of $\mathrm{NaCl}$ affected cooking time of patties cooked by microwaving.

In the previous our study (Choi et al., 2008b), the $\mathrm{pH}$ of reheated pork patties was not different compared with cooked patties and the $\mathrm{pH}$ of phosphate treatments had higher. El-Shimi (1992) and Keeton (1983) found that the $\mathrm{pH}$ of beef and pork patties was not affected by cooking method and $\mathrm{NaCl} /$ phosphate level. Therefore, it can be said that phosphate in patties helps keep high $\mathrm{pH}$ even after reheated and the cooking method also have an influence on the $\mathrm{pH}$ of patties. These results affected the instrumental color of reheated patties.

The instrumental color characteristics of ground pork patties with different $\mathrm{NaCl} /$ phosphate level are presented in Table 5 and 6. All parameters in surface color of patties reheated by electric grill did not have significantly different among the treatments with different $\mathrm{NaCl} /$ phosphate levels, except for CIE $\mathrm{L}^{*}(p>0.05)$. But the phosphate treatments reheated by microwave oven had lower CIE L*

Table 4. Comparison on the visual color properties of the cooked pork patties with different $\mathrm{NaCl} / \mathrm{phosphate}$ levels

\begin{tabular}{lcccc}
\hline \hline \multirow{2}{*}{ Traits } & \multicolumn{3}{c}{ Treatments $^{1)}$} \\
\cline { 2 - 5 } & $\mathrm{N} 1$ & $\mathrm{~N} 1+\mathrm{P}$ & $\mathrm{N} 2$ & $\mathrm{~N} 2+\mathrm{P}$ \\
\hline Surface color & $7.74 \pm 0.76^{\mathrm{B}}$ & $7.98 \pm 0.78^{\mathrm{B}}$ & $7.88 \pm 0.82^{\mathrm{B}}$ & $8.26 \pm 0.61^{\mathrm{A}}$ \\
Internal color & $7.35 \pm 0.72$ & $7.74 \pm 0.71$ & $7.62 \pm 0.80$ & $7.84 \pm 0.68$ \\
Overall appearance & $8.14 \pm 0.79$ & $8.43 \pm 0.77$ & $8.38 \pm 0.80$ & $8.66 \pm 0.71$ \\
\hline
\end{tabular}

All values are means \pm standard deviation.

${ }^{1)}$ The abbreviations are the same as in Table 2.

All raw patties were cooked by electric grill.

${ }^{A-C}$ Mean values with different superscripts within a same row are significantly different $(p<0.05)$.

Table 5. Comparison on the reheating time and surface color characteristics of the reheated pork patties with different $\mathrm{NaCl} /$ phosphate levels ${ }^{1)}$

\begin{tabular}{|c|c|c|c|c|c|c|c|c|}
\hline \multirow{2}{*}{ Traits } & \multicolumn{4}{|c|}{ Electric grill reheating } & \multicolumn{4}{|c|}{ Microwave oven reheating } \\
\hline & N1 & $\mathrm{N} 1+\mathrm{P}$ & $\mathrm{N} 2$ & $\mathrm{~N} 2+\mathrm{P}$ & N1 & $\mathrm{N} 1+\mathrm{P}$ & $\mathrm{N} 2$ & $\mathrm{~N} 2+\mathrm{P}$ \\
\hline Reheating time (s) & $745.2 \pm 23.1^{\mathrm{A}}$ & $751.8 \pm 31.5^{\mathrm{A}}$ & $748.5 \pm 28.4^{\mathrm{A}}$ & $760.9 \pm 19.5^{\mathrm{A}}$ & $140.2 \pm 11.2^{\mathrm{C}}$ & $167.1 \pm 24.3^{\mathrm{BC}}$ & $156.5 \pm 21.5^{\mathrm{BC}}$ & $177.4 \pm 22.6^{\mathrm{B}}$ \\
\hline $\mathrm{CIE} \mathrm{L}^{*}$ & $53.54 \pm 2.09^{\mathrm{B}}$ & $53.32 \pm 2.00^{\mathrm{B}}$ & $52.70 \pm 2.54^{\mathrm{C}}$ & $52.44 \pm 2.09^{\mathrm{C}}$ & $55.73 \pm 2.45^{\mathrm{A}}$ & $54.07 \pm 3.50^{\mathrm{AB}}$ & $55.36 \pm 3.07^{\mathrm{A}}$ & $53.05 \pm 2.38^{\mathrm{B}}$ \\
\hline $\mathrm{CIE} \mathrm{a}^{*}$ & $6.88 \pm 0.73^{\mathrm{A}}$ & $6.79 \pm 0.70^{\mathrm{A}}$ & $6.85 \pm 0.71^{\mathrm{A}}$ & $6.94 \pm 0.68^{\mathrm{A}}$ & $4.43 \pm 0.58^{\mathrm{C}}$ & $5.00 \pm 0.65^{\mathrm{BC}}$ & $4.65 \pm 0.53^{\mathrm{C}}$ & $5.35 \pm 0.96^{\mathrm{B}}$ \\
\hline $\mathrm{CIE} \mathrm{b}^{*}$ & $13.51 \pm 1.28$ & $12.84 \pm 1.26$ & $13.05 \pm 1.12$ & $12.82 \pm 1.02$ & $13.07 \pm 1.36$ & $12.46 \pm 1.10$ & $13.31 \pm 1.32$ & $12.95 \pm 1.28$ \\
\hline Hue angle & $62.86 \pm 4.09^{C}$ & $61.98 \pm 3.56^{\mathrm{C}}$ & $62.17 \pm 3.87^{\mathrm{C}}$ & $61.54 \pm 2.56^{\mathrm{C}}$ & $71.11 \pm 3.09^{\mathrm{A}}$ & $68.07 \pm 2.83^{\mathrm{B}}$ & $70.57 \pm 3.43^{\mathrm{AB}}$ & $67.44 \pm 4.90^{\mathrm{B}}$ \\
\hline S-chroma & $15.19 \pm 1.02^{\mathrm{A}}$ & $14.55 \pm 1.13^{\mathrm{AB}}$ & $14.77 \pm 0.89^{\mathrm{AB}}$ & $14.59 \pm 1.05^{\mathrm{AB}}$ & $13.82 \pm 1.28^{\mathrm{B}}$ & $13.44 \pm 1.10^{\mathrm{B}}$ & $14.12 \pm 1.17^{\mathrm{AB}}$ & $14.06 \pm 1.10^{\mathrm{AB}}$ \\
\hline
\end{tabular}

All values are means \pm standard deviation.

${ }^{1)}$ The abbreviations are the same as in Table 2.

${ }^{\mathrm{A}-\mathrm{C}}$ Mean values with different superscripts within a same row are significantly different $(p<0.05)$. 


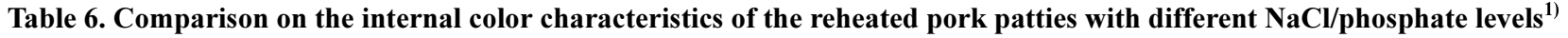

\begin{tabular}{|c|c|c|c|c|c|c|c|c|}
\hline \multirow{2}{*}{ Traits } & \multicolumn{4}{|c|}{ Electric grill reheating } & \multicolumn{4}{|c|}{ Microwave oven reheating } \\
\hline & N1 & $\mathrm{N} 1+\mathrm{P}$ & $\mathrm{N} 2$ & $\mathrm{~N} 2+\mathrm{P}$ & N1 & $\mathrm{N} 1+\mathrm{P}$ & $\mathrm{N} 2$ & $\mathrm{~N} 2+\mathrm{P}$ \\
\hline$\overline{\text { CIE L }^{*}}$ & $68.10 \pm 1.24^{\mathrm{A}}$ & $66.43 \pm 0.53^{\mathrm{AB}}$ & $65.59 \pm 1.21^{\mathrm{B}}$ & $64.48 \pm 0.48^{\mathrm{BC}}$ & $67.18 \pm 1.46^{\mathrm{AB}}$ & $65.64 \pm 0.90^{\mathrm{B}}$ & $65.08 \pm 1.09^{\mathrm{B}}$ & $63.18 \pm 0.54^{\mathrm{C}}$ \\
\hline CIE $a^{*}$ & $3.62 \pm 0.37^{\mathrm{B}}$ & $4.67 \pm 0.45^{\mathrm{A}}$ & $3.76 \pm 0.36^{\mathrm{B}}$ & $4.84 \pm 0.44^{\mathrm{A}}$ & $3.57 \pm 0.46^{\mathrm{B}}$ & $3.90 \pm 0.45^{\mathrm{B}}$ & $3.80 \pm 0.47^{\mathrm{B}}$ & $4.43 \pm 0.40^{\mathrm{AB}}$ \\
\hline $\mathrm{CIE}^{*}{ }^{*}$ & $9.49 \pm 0.75^{\mathrm{AB}}$ & $8.90 \pm 0.87^{\mathrm{AB}}$ & $8.71 \pm 0.96^{\mathrm{B}}$ & $8.40 \pm 0.65^{\mathrm{B}}$ & $10.29 \pm 0.78^{\mathrm{A}}$ & $9.51 \pm 0.99^{\mathrm{AB}}$ & $10.00 \pm 1.04^{\mathrm{A}}$ & $9.26 \pm 0.83^{\mathrm{AB}}$ \\
\hline Hue angle & $69.04 \pm 2.64^{\mathrm{A}}$ & $62.12 \pm 4.37^{\mathrm{AB}}$ & $66.53 \pm 2.66^{\mathrm{AB}}$ & $59.98 \pm 3.49^{\mathrm{C}}$ & $70.20 \pm 3.38^{\mathrm{A}}$ & $67.46 \pm 3.95^{\mathrm{AB}}$ & $69.50 \pm 3.75^{\mathrm{A}}$ & $64.37 \pm 2.10^{\mathrm{AB}}$ \\
\hline S-chroma & $10.17 \pm 0.70$ & $10.07 \pm 0.61$ & $9.50 \pm 0.92$ & $9.71 \pm 0.52$ & $10.63 \pm 0.67$ & $10.30 \pm 0.83$ & $10.99 \pm 0.90$ & $10.28 \pm 0.85$ \\
\hline
\end{tabular}

All values are means \pm standard deviation.

${ }^{1)}$ The abbreviations are the same as in Table 2.

${ }^{A-C}$ Mean values with different superscripts within a same row are significantly different $(p<0.05)$.

and hue angle values, higher $\mathrm{a}^{*}$-value (less brownish and more intense red) than those without phosphate $(p<0.05)$. The surface color of the patties reheated by microwave oven showed higher $\mathrm{L}^{*}$-value and hue angle (more brown), lower a*-value and S-chroma (less intense red). As increased the addition of $\mathrm{NaCl}$ and phosphate, the internal $\mathrm{L}^{*}$ value decreased and the reheated patties using microwave oven had lower $\mathrm{L}^{*}$-value than those using electric grill, on the contrary to the result of surface $\mathrm{L}^{*}$-value. CIE a ${ }^{*}$-value of phosphate treatments using electric grill were higher than the other treatments (more reddish), but the CIE $b^{*}$ value of treatments without phosphate $(\mathrm{N} 1, \mathrm{~N} 2)$ using microwave oven were higher than $\mathrm{N} 2$ and $\mathrm{N} 2+\mathrm{P}$ treatments using electric grill $(p<0.05)$. The internal hue angle was affected by the addition of phosphate. But there did not have significant differences in S-chroma between treatments with different $\mathrm{NaCl} /$ phosphate levels and reheating methods $(p>0.05)$. Neer and Mandigo (1977) found that a flaked and cured products became darker as the $\mathrm{NaCl}$ increased to $1.5 \%$, and then increased in redness with increased $\mathrm{NaCl}$. This was also seen in our study. Many factors influence a cooked ground beef color, resulting in a persistent pinking (Trout, 1989), or a premature browning (Warren et al., 1996; Hunt et al, 1999). Especially, Ryan et al. (2006) reported that a rapid cooking versus a slow cooking to the same endpoint temperature of ground beef patties results in a pinker, less well- done cooked appearance. Thus, microwave oven reheating obtained more desirable reheating color compared to electric grill reheating.

\section{Myoglobin denaturation and percent metmyoglobin}

Table 7 shows the myoglobin denaturation $(\mathrm{MbD})$ and percent metmyoglobin $(\mathrm{PMb})$ of reheated pork patties with different $\mathrm{NaCl} /$ phosphate levels. The total heat energy delivered to a complex meat system is important to the thermal denaturation of myoglobin (Mohsenin, 1980). The myoglobin denaturation had the extent of $79-81 \%$ in all treatments. However, no significant differences existed among either reheating methods or $\mathrm{NaCl} /$ phosphate levels $(p>0.05)$. Myoglobin denaturation in the reheated patties was increased by an average of $14 \%$ than that in the cooked patties. Our results were similar with Lien et al. (2002), who showed that the myoglobin denaturation of pork patties cooked at $76.7^{\circ} \mathrm{C}$ had a range of 84 to $86 \%$. Brewer and Novakofski (1999) reported that cooked color was not influenced by cooking rates $\left(0.7\right.$ and $\left.3.0^{\circ} \mathrm{C} / \mathrm{min}\right)$. On the other hand, the reheated patties contained $90-91 \%$ metmyoglobin regardless of $\mathrm{NaCl} /$ phosphate levels and reheating methods $(p>0.05)$. In the manufacture of restructured meat products, the addition of sodium chloride (Rhee et al., 1983; Trout, 1989) and cooking condition (Hood, 1980; Sherwin and Labuza, 2003) are known to affect discoloration. But because the patties cooked at

Table 7. Comparison on the myoglobin denaturation (Mbd) and percent metmyoglobin (PMb) of the reheated pork patties with different $\mathrm{NaCl} /$ phosphate levels ${ }^{1}$

\begin{tabular}{|c|c|c|c|c|c|c|c|c|}
\hline \multirow{2}{*}{ Traits } & \multicolumn{4}{|c|}{ Electric grill reheating } & \multicolumn{4}{|c|}{ Microwave oven reheating } \\
\hline & N1 & $\mathrm{N} 1+\mathrm{P}$ & N2 & $\mathrm{N} 2+\mathrm{P}$ & N1 & $\mathrm{N} 1+\mathrm{P}$ & N2 & $\mathrm{N} 2+\mathrm{P}$ \\
\hline $\mathrm{MbD}(\%)$ & $80.08 \pm 3.04$ & $79.44 \pm 2.32$ & $79.98 \pm 1.69$ & $79.65 \pm 2.02$ & $80.63 \pm 1.71$ & $80.37 \pm 2.82$ & $79.79 \pm 2.37$ & $79.28 \pm 1.51$ \\
\hline $\mathrm{PMb}(\%)$ & $90.77 \pm 5.49$ & $89.79 \pm 5.51$ & $90.97 \pm 6.13$ & $88.93 \pm 3.95$ & $91.04 \pm 3.37$ & $90.00 \pm 4.09$ & $90.24 \pm 4.38$ & $90.89 \pm 2.78$ \\
\hline
\end{tabular}

All values are means \pm standard deviation.

${ }^{1)}$ The abbreviations are the same as in Table 2.

$\mathrm{MbD}=$ myoglobin denaturation, $\mathrm{PMb}=$ percent metmyoglobin. 


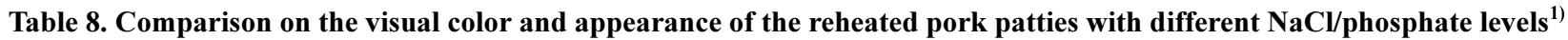

\begin{tabular}{|c|c|c|c|c|c|c|c|c|}
\hline \multirow{2}{*}{ Traits } & \multicolumn{4}{|c|}{ Electric grill reheating } & \multicolumn{4}{|c|}{ Microwave oven reheating } \\
\hline & N1 & $\mathrm{N} 1+\mathrm{P}$ & $\mathrm{N} 2$ & $\mathrm{~N} 2+\mathrm{P}$ & N1 & $\mathrm{N} 1+\mathrm{P}$ & N2 & $\mathrm{N} 2+\mathrm{P}$ \\
\hline Surface color & $7.56 \pm 0.68$ & $7.68 \pm 0.71$ & $7.76 \pm 0.58$ & $7.88 \pm 0.73$ & $7.34 \pm 0.70$ & $7.42 \pm 0.68$ & $7.48 \pm 0.64$ & $7.50 \pm 0.61$ \\
\hline Internal color & $7.25 \pm 0.71$ & $7.44 \pm 0.76$ & $7.56 \pm 0.68$ & $7.53 \pm 0.75$ & $7.23 \pm 0.65$ & $7.32 \pm 0.61$ & $7.33 \pm 0.68$ & $7.40 \pm 0.71$ \\
\hline Overall appearance & $8.01 \pm 0.66$ & $8.36 \pm 0.70$ & $8.14 \pm 0.68$ & $8.43 \pm 0.78$ & $7.21 \pm 0.72$ & $7.33 \pm 0.66$ & $7.35 \pm 0.67$ & $7.45 \pm 0.67$ \\
\hline
\end{tabular}

All values are means \pm standard deviation.

1) The abbreviations are the same as in Table 2.

more than $75^{\circ} \mathrm{C}$ when cooking, most of myoglobin denaturated by high temperature rather than affected by salt and phosphate. Thus, myoglobin denaturation affect by cooking temperature rather than salt concentration. The result of the present study showed that myogobin denaturation and metmyoglobin contents were affected by reheating conditions rather than $\mathrm{NaCl} /$ phosphate content level.

\section{Visual color and appearance properties}

The visual color and appearance properties of reheated pork patties with different $\mathrm{NaCl} /$ phosphate levels are shown in Table 8. With respect to visual color, there were no significant difference among all treatments in the surface as well as internal color $(p>0.05)$. Because all treatments were evaluated on high score more than 7 points, all patties cooked seemed well done. But sensory panel members didn't detect differences about color of reheated patties between treatments. The overall appearance of reheated patties by electric grill received a higher sensory score than those by microwave oven, but no significant differences were found between the reheating methods $(p>0.05)$. Also, $\mathrm{NaCl} / \mathrm{phosphate}$ levels didn't affect on visual color and overall appearance. The appearance of cooked meat products can be influenced by $\mathrm{pH}$, meat source, packaging conditions, freezing history, fat content, added ingredients and preservation treatments such as irradiation and pressure (King and Whyte, 2006). Froning (1966) reported that the addition of phosphates tended to darken the meat, while other workers observed that phosphates improve the color of the finished products (Vollmar and Melton, 1981; Wierbicki et al., 1976). But the present study found that the addition of phosphate improved sensory color of cooked patties, but didn't affect on the sensory color of reheated patties. Thus, the visual color of reheated patties was influenced by reheating methods rather than ingredients.

The results of this study indicated that reheating methods affected surface color of reheated patty, except for inner color. Also, microwave oven reheating obtained more desirable reheating color compared to electric grill reheating. As increased the addition of $\mathrm{NaCl}$ and phosphate, internal color of patties had more reddish. Therefore, in order to eat the reheated patties with desirable color, the consumers need to consider the reheating conditions and added ingredients when reheating the restructured meat products.

\section{Acknowledgment}

This article was supported by the Brain Korean 21 (BK 21) Project from Ministry of Education and Human Resources Development, Republic of Korea.

\section{References}

1. Barbut, S. and Mittal, G. S. (1990) Effect of heating rate on meat batter stability, texture and gelation. J. Food Sci. 55, 334-337.

2. Berry, B. W. and Leddy, K. F. (1984) Effects of fat level and cooking method on sensory and textural properties of ground beef patties. J. Food Sci. 49, 870-875.

3. Brewer, M. S. and Novakofski, J. (1999) Cooking rate, pH and final endpoint temperature effects on colour and cook loss of a lean ground beef model system. Meat Sci. 52, 443451.

4. Brican, C. and Barringer, S. A. (2002) Determination of protein denaturation of muscle foods using the dielectric properties. J. Food Sci. 67, 202-205.

5. Brown, W. D. and Mebine, L. B. (1969) Autoxidation of oxymyoglobins. J. Biol. Chem. 244, 6696-6701.

6. Choi, J. H., Jeong, J. Y., Choi, Y. S., Lee, E. S., and Kim, C. J. (2008a) The relationship between fat level and quality properties of ground pork patties cooked by microwave energy. Korean J. Food Sci. Ani. Resour. 28, 295-300.

7. Choi, J. H., Jeong, J. Y., Kim, H. Y., An, K. I., and Kim, C. J. (2008b) The effects of electric grill and microwave oven reheating methods on the quality characteristics of precooked ground pork patties with different $\mathrm{NaCl}$ and phosphate levels. Korean J. Food Sci. Ani. Resour. 28, 535-542.

8. Chung, M. S. and Chung, S. S. (1993) Quality changes of ground beef patties cooked by conventional and microwave energy during refrigerated storage. Food Sci. Biotechnol. 2, 
80-83.

9. Cremer, M. L. and Hartley, S. K. (1988) Sensory quality of turkey rolls roasted at two temperatures and reheated with varying sauces in three types of institutional ovens. J. Food Sci. 53, 1605-1609.

10. El-Shimi, N. H. (1992) Influence of microwave and conventional cooking and reheating on sensory and chemical characteristics of roast beef. Food Chem. 45, 11-14.

11. Froning, G. W. (1966) Effect of various additives on the binding properties of chicken meat. Poultry Sci. 45, 185-188.

12. Hague, M. E., Warren, K. E., Hunt, M. C., Kropt, D. H., Kastner, C. L., Stroda, S. L., and Johnson, D. E. (1994) Endpoint temperature, internal cooked color, and expressible juice color relationships in ground beef patties. J. Food Sci. 59, 465-470.

13. Hood, D. E. (1980) Factors affecting the rate of metmyoglobin accumulation in pre-packaged beef. Meat Sci. 4, 247265.

14. Hunt, M. C., Sørheim, O., and Slinde, E. (1999) Color and heat denaturation of myoglobin forms in ground beef. $J$. Food Sci. 64, 847-851.

15. Hunter, R. S. and Harold, R. W. (1987) The measurement of appearance. 2nd ed, John Wiley and Sons, Inc., NY, pp. 123125.

16. Jeong, J. Y., Lee, E. S., Choi, J. H., Lee, J. Y., Kim, J. M., Min, S. G., Chae, Y. C., and Kim, C. J. (2007) Variability in temperature distribution and cooking properties of ground pork patties containing different fat level and with/without salt cooked by microwave energy. Meat Sci. 75, 415-422.

17. Jeong, J. Y., Lee, E. S., Paik, H-. D., Choi, J. H., and Kim, C. J. (2004) Microwave cooking properties of ground pork patties as affected by various fat levels. J. Food Sci. 69, 708712.

18. Keeton, J. T. (1983) Effect of fat and $\mathrm{NaCl} /$ phosphate levels on the chemical and sensory properties of pork patties. $J$. Food Sci. 48, 878-881, 885.

19. King, N. J. and Whyte, R. (2006) Does it look cooked? A review of factors that influence cooked meat color. J. Food Sci. 71, R31-R40.

20. Kirchner, J. M., Beasley, L. C., Harris, K. B., and Savell, J. W. (2000) Evaluating the cooking and chemical characteristics of low-fat ground beef patties. J. Food Comp. Anal. 13, 253-264.

21. Korschgen, B. M. and Baldwin, R. E. (1978) Moist-heat microwave and conventional cooking of round roasts of beef. J. Microwave Power E.E. 13, 257-262.

22. Krzywicki, K. (1979) Assessment of relative content of myoglobin, oxymyoglobin and metmyoglobin at the surface of beef. Meat Sci. 3, 1-10.

23. Liu, M. N. and Berry, B. W. (1996) Variability in color, cooking times, and internal temperature of beef patties under controlled cooking conditions. J. Food Protect. 59, 969-975.

24. Lien, R., Hunt, M. C., Anderson, S., Kropf, D. H., Loughin, T. M., Dikeman, M. E., and Velazco, J. (2002) Effects of endpoint temperature on the internal color of pork patties of different myoglobin form, initial cooking state, and quality $J$.
Food Sci. 67, 1011-1015.

25. Mohsenin, N. N. (1980) Thermal properties of foods and agricultural materials. Gordon and Breach Science Publishers, NY, pp. 83- 118.

26. Neer, K. L. and Mandigo, R. W. (1977) Effects of salt, sodium tripolyphosphate and frozen storage time on properties of a flaked, cured pork product. J. Food Sci. 42, 738-742.

27. Offer, G. and Trinick, J. (1983) On the mechanism of water holding in meat: the swelling and shrinking in myofibrils. Meat Sci. 8, 245-281.

28. Rhee, K. S., Terrell, R. N., Quintanilla, M., and Vanderzant, C. (1983) Effect of addition of cloride salts on rancidity of ground pork inoculated with a moraxella or a Lactobacillus species. J. Food Sci. 48, 302-303.

29. Ryan, S. M., Seyfert, M., Hunt, M. C., and Mancini, R. A. (2006) Influence of cooking rate, endpoint temperature, post-cook hold time, and myoglobin redox state on internal color development of cooked ground beef patties. J. Food Sci. 71, C216-C221.

30. Ryyänen, S. (1995) The electromagnetic properties of food materials: a review of the basic principles. J. Food Eng. 26, 409-429.

31. Ryyänen, S. and Ohlsson, T. (1996) Microwave heating uniformity of ready meals as affected by placement, composition, and geometry. J. Food Sci. 61, 620-624.

32. Ryyänen, S., Risman, P. O., and Ohlsson, T. (2004) Hamburger composition and microwave heating uniformity. $J$. Food Sci. 69, M187-M196.

33. SAS. (1999) SAS User's Guide. Cary, NC, USA: Statistical Analysis Systems Institute.

34. Serrano, A., Liblelotto, J., Cofrades, S., Sánchez-Muniz, F. J., and Jiménez-Colmenero, F. (2007) Composition and physicochemical characteristics of restructured beef steaks containing walnuts as affected by cooking method. Meat Sci. 77, 304-313.

35. Sherwin, C. P. and Labuza, T. P. (2003) Role of moisture in maillard browning reaction rate in intermediate moisture foods: Comparing solvent phase and matrix properties. $J$. Food Sci. 68, 588-594.

36. Shiffman, R. F. (1986) Food product development for microwave processing. Food Technol. 40, 94-98.

37. Trout, G. R. (1989) Variation in myoglobin denaturation and colour of cooked beef, pork, and turkey meat as influenced by $\mathrm{pH}$, sodium chloride, sodium tripolyphosphate, and cooking temperature. J. Food Sci. 54, 536-540, 544.

38. Trout, G. R. and Dale, S. (1990) Prevention of warmed-over flavor in cooked beef: effect of phosphate type, phosphate concentration, a lemon juice/phosphate blend, and beef extract. J. Agric. Food Chem. 38, 665-669.

39. Vollmar, E. K. and Melton, C. C. (1981) Selected quality factors and sensory attributes of cured ham as influenced by different phosphate blends. J. Food Sci. 46,317-320, 327.

40. Wallace, W. J., Houtchens, R. A., Maxwell, J. C., and Caughey, W. S. (1982) Mechanism of autoxidation for hemoglobins and myoglobins. promotion of superoxide production by protons and anions. J. Biol. Chem. 257, 4966-4977 
41. Warren, K. E., Hunt, M. C., and Kropf, D. H. (1996) Myoglobin oxidative state affects internal cooked color development in ground beef patties. J. Food Sci. 61, 513-515, 519.

42. Warris, P. D. (1979) The extraction of haem pigments form fresh meat. J. Food Technol. 14, 75-80.

43. Wierbicki, E., Howker, J. J., and Shults, G. W. (1976) Effect of salt, phosphates and other curing ingredients on shrinkage of lean pork meat and the quality of smoked processed ham. J. Food Sci. 41, 1116-1121.

44. Zimmermann, W. J. (1984) Microwave recooking of pork roasts to attain $76.7^{\circ} \mathrm{C}$ throughout. J. Food Sci. 49, 970-971, 974.

(Received 2010.6.1/Revised 2010.7.12/Accepted 2010.7.16) 